\title{
The effect of continentality on glacier response and mass balance
}

\author{
Per Holmlund, Thomas Schneider \\ Department of Physical Geography, Stockholm University, S-106 91 Stockholm, Sweden
}

\begin{abstract}
The continentality index is a good measure of the nature of the climate in a region, as it reflects not only the temperature but also the large-scale circulation. It correlates well with glacier mass-balance parameters. The climate along the west-east transect slightly north of the Arctic Circle across the Scandinavian Caledonides is governed by the prevailing westerlies; however, during winter the eastern part of the Caledonides is influenced by weather systems from the southeast. The differences in continentality meant by temperature and precipitation have a major impact on the response times of glaciers. The climatic change in this area has been dominated by increased summer mean temperatures (1910-20) and increased maritime influence since the $1980 \mathrm{~s}$. The slower-reacting glaciers on the Swedish side of the mountains are still adapting to the temperature increase at the beginning of the 20th century, and the increase in maritime influence gradually becomes less important towards the west. Thus, differences in the behaviour of glacier fronts along the west-east transect mirror differences in continentality.
\end{abstract}

\section{INTRODUCTION}

Glaciers are known as good climatic indicators. Changes in glacier length are used as delayed and filtered proxy information about climate variables such as temperature and precipitation. High resolution is obtained using annual massbalance data, a high-quality but time-consuming and expensive way of monitoring glaciers. A mass-balance record is the key to climatic fluctuations, while front position changes are much more difficult to interpret, especially in cold and continental areas where glacier response times are long. A proxy measurement of the net mass balance is the size of the accumulation area at the end of a melt season, often referred to as accumulation area ratio (AAR). Assuming a balanced state and a constant net balance

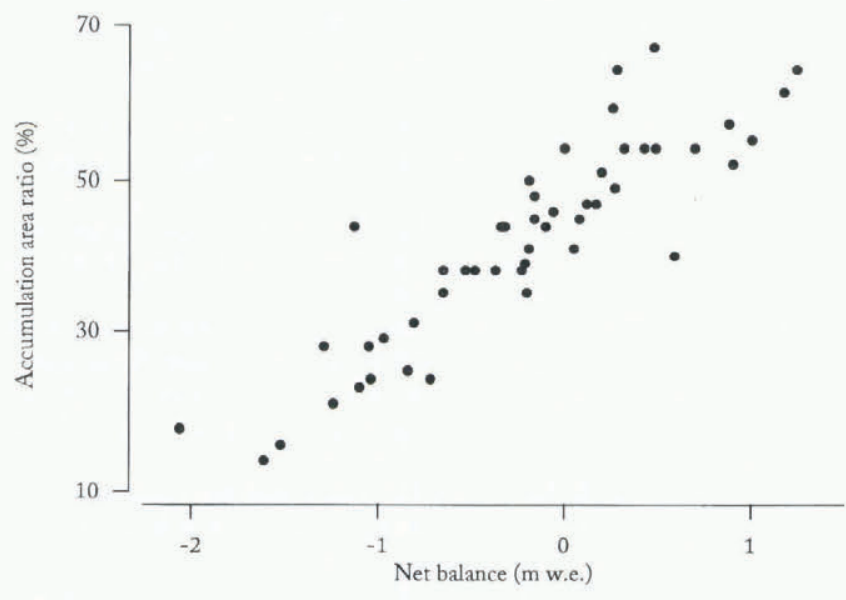

Fig. 1. The correlation between accumulation area ratio (AAR) and the net balance of Storglaciären highlights the validity of using $A A R$ as proxy measurements for mass balance.

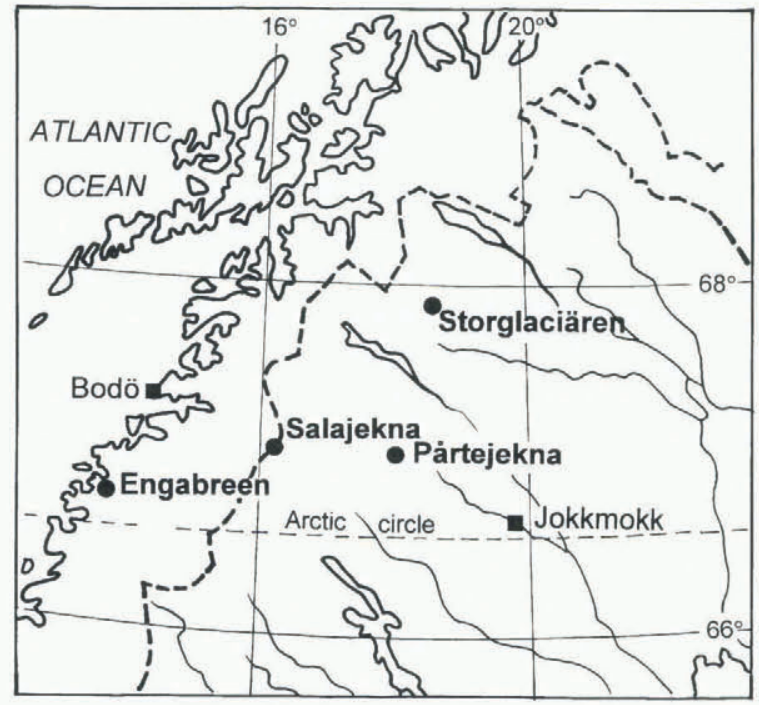

Fig. 2. Location map showing sites mentioned in the text.

gradient, AAR is expected to correlate well with the net balance and thus the climate (Fig. 1).

In this study we compare some AAR observations with a continentality index along a transect from the west coast of Norway to inland Sweden. The aim is to show the importance of clarifying whether glacier changes are due to local climate effects or large-scale trends when studying glaciers as climate indicators.

We used climate data from the two national weather stations in Bodø (Norway) and Jokkmokk (Sweden), and from our own stations at Sulitelma and Pårtetjåkkå, both in Sweden (Fig. 2; Table 1). Data on glaciers were taken from Engabreen on the Norwegian coast, Salajekna at the water divide and Pårtejekna on the eastern side of the mountains. 
Table 1. Meteorological characteristics of four stations along a west-east transect located slightly north of the Arctic Circle in Scandinavia (Fig. 2). Data from Bodo and Jokkmokk provided by the Norwegian and Swedish weather services, respectively

\begin{tabular}{|c|c|c|c|c|c|c|c|c|c|c|}
\hline & \multicolumn{4}{|c|}{ Summer temperature } & \multicolumn{4}{|c|}{ Continentality index } & \multicolumn{2}{|c|}{ Winter precipitation } \\
\hline & Bode & Salajekna & Pairtejekna & Jokkmokk & Bodo & Salajekna & Pärlejekna & Jokkmokk & Bodo & Jokkmokk \\
\hline & ${ }^{\circ} \mathrm{C}$ & ${ }^{\circ} \mathrm{C}$ & ${ }^{\circ} \mathrm{C}$ & ${ }^{\circ} \mathrm{C}$ & ${ }^{\circ} \mathrm{C}$ & ${ }^{\circ} \mathrm{C}$ & ${ }^{\circ} \mathrm{C}$ & ${ }^{\circ} \mathrm{C}$ & $\mathrm{mm}$ & $\mathrm{mm}$ \\
\hline 1989 & 11.4 & & & 12.5 & 14.1 & & & 26.8 & 765 & 218 \\
\hline 1990 & 12.6 & & & 13.2 & 15.4 & & & 29.5 & 623 & 222 \\
\hline 1991 & 12.1 & & & 13.0 & 14.4 & & & 33.6 & 552 & 219 \\
\hline 1992 & 12.3 & & & 12.4 & 11.9 & & & 22.6 & 721 & 219 \\
\hline 1993 & 12.1 & & & 11.7 & 14.3 & & & 26.6 & 638 & 195 \\
\hline 1994 & 11.7 & & & 12.9 & 17.0 & & & 35.5 & 379 & 241 \\
\hline 1995 & 10.6 & 4.3 & 0.8 & 12.2 & 11.2 & 13.8 & 15.1 & 23.0 & 732 & 220 \\
\hline
\end{tabular}

\section{DESCRIPTION OF THE GLACIERS STUDIED}

\section{Engabreen}

Engabreen's areal extension is $32 \mathrm{~km}^{2}$, and it is part of western Svartisen covering $221 \mathrm{~km}^{2}$ (Fig. 2). Its vertical extension ranges between 40 and $1594 \mathrm{~m}$ a.s.l. It is a temperate, valley-type, outlet glacier. The extension of the glacier has been documented since the mid-18th century, and the first photograph was taken in 1881. At this time Engabreen covered the lake Engavannet, and the front was only a few hundred metres from the sea at an elevation of $10 \mathrm{~m}$. The front of Engabreen showed only minor fluctuations until about 1930 when it suddenly began to retreat rapidly. Around 1950, the $1500 \mathrm{~m}$ long Engavannet was entirely exposed. After this, the terminus fluctuated back and forth over a few hundred metres until recently when the glacier began advancing significantly (personal communication from N. Haakensen, 1996) (Table 2).

Mass-balance measurements were initiated in 1966. After a few years with a balanced state the glacier has since had a positive mass balance. The glacier has grown $15 \mathrm{~m}$ thicker on average since 1972 (Haeberli and others, 1994).

Table 2. Data on annual change in front position and on accumulation area ratio

\begin{tabular}{rrrrrrr}
\hline & \multicolumn{2}{c}{ Engabreen } & \multicolumn{2}{c}{ Salajekna } & \multicolumn{2}{c}{ Partejekna } \\
& $\mathrm{m}$ & $\%$ & $\mathrm{~m}$ & $\%$ & $\mathrm{~m}$ & $\%$ \\
& & & & & & \\
\hline 1989 & -22 & 93 & -5 & & -7 & \\
1990 & -22 & 84 & -5 & 70 & -7 & 42 \\
1991 & -24 & 75 & -5 & & -7 & \\
1992 & 0 & 94 & -5 & 71 & -4 & 48 \\
1993 & 18 & 87 & -7 & & -6 & 52 \\
1994 & 58 & 76 & -7 & 56 & -6 & 9 \\
1995 & 58 & 91 & -13 & 80 & 9 & 30 \\
& & & & & & \\
\hline
\end{tabular}

\section{Salajekna}

Salajekna is situated in the Sulitelma massif at the border between Sweden and Norway (Fig. 2). It is a valley-type glacier in a glacier complex covering $\sim 30 \mathrm{~km}^{2}$. Salajekna proper has an areal extension of $24 \mathrm{~km}^{2}$, a volume of approximately $2.4 \mathrm{~km}^{3}$ and a vertical range between 880 and
$1580 \mathrm{~m}$ a.s.l. (Ostrem, 1983). The glacier is oriented towards the south.

The first scientific observation of a Swedish glacier was made in 1807 on Salajekna by Wahlenberg (1808). He described the glacier in a figurative way; he heard continuous audible cracking and water running underneath the glacier. Fortunately, he also made a painting of the glacier from a nearby frontier cairn on the border between Norway and Sweden.

In 1897 the glacier was photographed from the same frontier cairn used by Wahlenberg. The panoramic view shows that Salajekna was heavily crevassed by then and had a greater extension than in 1807 (Westman, 1899). Later lichenometric studies by P. Karlén (personal communication, 1996) show that the glacier had an extension very close to its Holocene maximum at the turn of the 19th century. Westman made front observations during a 10 year period over the extensive phase of the glacier (Westman, 1910). He also drew a map of the glacier (Westman, 1899).

In 1965 the glacier was included in the official Swedish glacier monitoring programme, and the snout has been regularly surveyed since then by means of frontal changes (Schytt, 1968; Holmlund, 1993). The glacier has retreated about $1.5 \mathrm{~km}$ with annual recession rates of $15-20 \mathrm{~m}$ since 1910, though the recession speed is now declining (Table 2). The most accurate map is based on aerial photographs taken in 1980 and printed at a scale of 1:20000 (Ostrem, 1983). Less than $5 \%$ of the ice mass is below freezing point, and Salajekna is thus referred to as a temperate glacier.

\section{Pårtejekna}

Pårtejekna is situated in the Pårte massif in southern Sarek National Park (Fig. 2). It is a valley glacier oriented east, with a divided accumulation area. Its areal extension is $11.1 \mathrm{~km}^{2}$, its volume approximately $0.88 \mathrm{~km}^{3}$ and its vertical extension ranges from 1090 to $1760 \mathrm{~m}$ a.s.l. (Holmlund, 1995). The glacier was first described by Hamberg (1901, 1910) who made ablation measurements and documented the glacier photographically between 1897 and 1901. He called the glacier Lulevaggeglaciären, a name which is no longer in use. In 1965 Pårtejekna was included in the Swedish glacier-monitoring programme (Schytt, 1968; Holmlund, 1993). The glacier began its recession later (around 1930) than most other Swedish glaciers and is presently retreating at a speed of about $10 \mathrm{~m}$ year $^{-1}$. At present there is no sign of a decline in the recession rate (Table 2). There 
is no printed large-scale map of the glacier, though a xeroxed working map at a scale of 1:20000 is available at the Department of Physical Geography, Stockholm University. About $50 \%$ of the glacier mass is below freezing temperatures, and in most senses it is referred to as a sub-polar glacier (Holmlund, 1993; paper in preparation by P. Holmlund).

\section{DESGRIPTION OF GLIMATE STATIONS}

The climate stations used in this investigation are located on a west-east transect through the Scandinavian Caledonides from Bodø at the Norwegian coast in the west to Jokkmokk in the east (Fig. 2). The profile is located at a latitude of $\sim 67^{\circ} \mathrm{N}$. The stations Bodø and Jokkmokk are official weather stations in the Norwegian and Swedish weather services, respectively. Bodø is located at sea level, and Jokkmokk at an altitude of $263 \mathrm{~m}$ a.s.l. (Table 1).

The two other stations used in this study are run by the Tarfala Research Station. They are automatic weather stations located in front of Salajekna at an altitude of $900 \mathrm{~m}$ a.s.l., and on the top plateau of Pårtetjåkkå at an altitude of $1830 \mathrm{~m}$ a.s.l. (Fig. 2). The stations are equipped with a Campbell Scientific CR10 data logger and powered by solar panels. At Salajekna, temperature and relative humidity are measured by means of a Rotronic MP300 probe $2 \mathrm{~m}$ above ground. The station was installed in August 1994 (Table 1).

The observation site on Pårtetjåkkå is located near the former observatory of A. Hamberg, who carried out meteorological observations at the beginning of the 20th century (Hamberg, 1901; Hamberg and Jönsson, 1933). There are sporadic observations from 1901 to 1914 and continuous records from July 1914 until September 1918. Since August 1993, temperature has been measured in Hamberg's former radiation screen (Table 1 ), as well as $2 \mathrm{~m}$ above ground with the help of platinum resistance probes (Pt100), mounted in a Young radiation shield. The temperature data used in the present investigation are from the Pt100 in the Young shield. In August 1994 a Young wind monitor was installed $3 \mathrm{~m}$ above ground to measure wind speed and direction.

\section{CLIMATIC DEVELOPMENT DURING THE LAST 200 YEARS}

A strong climatic gradient can be distinguished along a latitudinal transect from the Atlantic Ocean to central Sweden. The climate in western Norway is maritime; at the water divide it is locally maritime; and east of the mountains it is locally continental ( $\AA$ ngström, 1974). This climatic gradient also influences net balance gradients on glaciers and the glaciation level. Typical values on net balance gradients are $1.5 \mathrm{~m}$ per $100 \mathrm{~m}$ in western Norway and $0.5 \mathrm{~m}$ per $100 \mathrm{~m}$ in the eastern part of the mountains. The glaciation level (Brückner, 1887) increases in the opposite direction at a gradient of approximately $0.7 \mathrm{~m} \mathrm{~km}^{-1}$ (Enquist, 1916). The rate of maritimity in the mountain area has varied with time. It was especially pronounced during the late 19th century (Wallén, 1986), as well as during the last 10 years (Holmlund, 1993; Grudd and Schneider, 1996; Holmlund and others, 1996). Changes in the rates of maritimity and continentality have almost certainly varied earlier during the Holocene.

There are a number of front moraines representing for- mer large glacier extensions during the Holocene in front of most Swedish glaciers. We cannot interpret the length of these cold periods from the moraines. However, from the time of the last glacier maximum, at the turn of the 19th century, we have climatic data and also information on length of periods. As the temperature records from northern Sweden indicate that the 19th century was colder than the present century, we must conclude that the precipitation rates were much lower than the present levels in order to prevent the glaciers from overriding their Holocene maxima. A dry, cold climate during the 19th century is also supported by balanced flow calculations on Mikkaglaciären (Holmlund, 1986).

At the beginning of the 20th century, summer mean temperatures increased and all Swedish glaciers responded with high rates of thinning and recession. Large glaciers of a more continental type responded more slowly to the new climate. Their recessions often began 10-15 years later than more maritime glaciers. At present, small and mediumsized glaciers $\left(<2 \mathrm{~km}^{2}\right)$ have adapted to the 20th-century climate, but the large ones are still retreating (Holmlund 1988, 1993, 1995).

\section{METHODS}

Changes in glacier front positions are measured annually at the end of the melting season (Table 2), and results are reported every fifth year to the World Glacier Monitoring Service (Haeberli and Hoelzle, 1993).

The AAR values on Salajekna and Pårtejekna are interpreted from oblique aerial photographs taken in connection with the front surveys at the end of summer. On Engabreen the AAR value describes the area upstream of the equilibrium line, which is based on mass-balance records (Table 2). The significance of using AAR as a proxy measurement for mass-balance data is described in Figure 1.

The continentality of the climate can be expressed by the temperature amplitude during a year (Liljequist, 1970). In our investigation we define the continentality index (CI) as the temperature amplitude during a mass-balance year, i.e. the difference between the temperature of the coldest winter month and that of the warmest month the following summer. High-pressure systems are associated with high summer and low winter temperatures and dry conditions. Low-pressure systems produce low summer and high winter

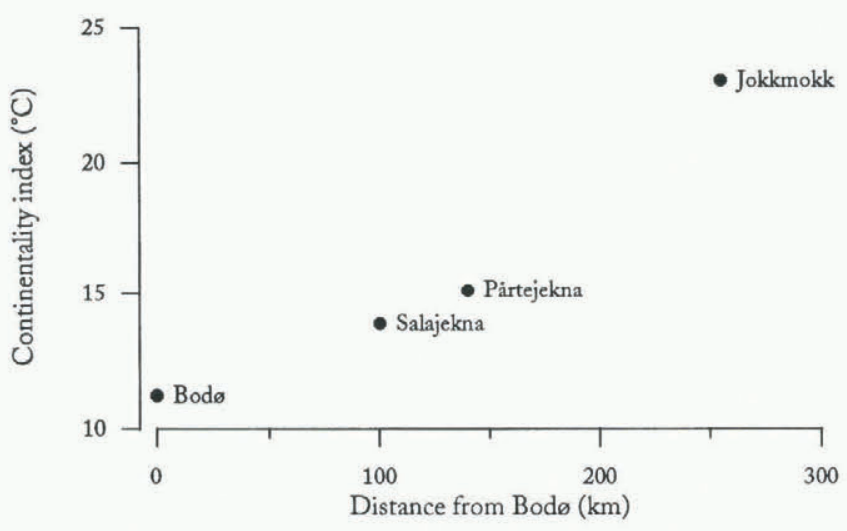

Fig. 3. Differences in continentality index along the west-east transect. 

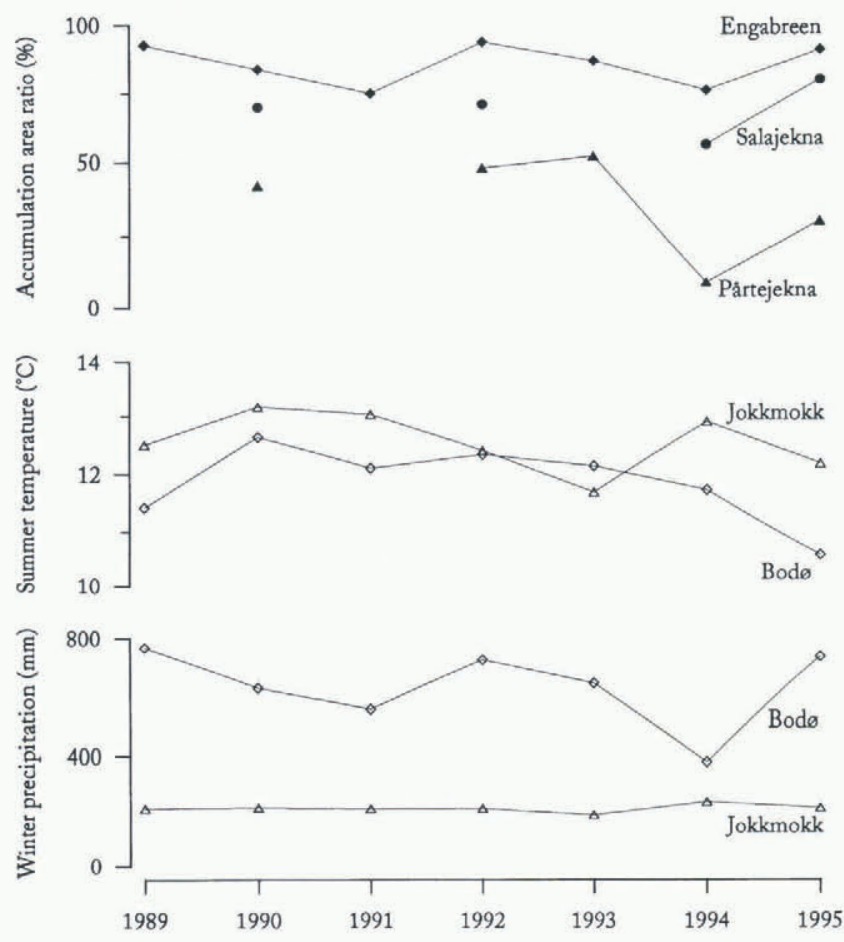

Fig. 4. The correlation between AAR values of Engabreen, Salajekna and Pårtejekna, and summer mean temperature, and winter precipitation at Bodo and Jokkmokk. Data provided by the weather service in northern. Norway and by the Swedish Institute for Meteorology and Hydrology (SMHI).

temperatures and high precipitation rates. Thus the CI also takes into account precipitation.

\section{RESULTS}

The continentality index increases from west to east (Fig. 3; Table 1). The CI gradient was calculated as $2.8^{\circ} \mathrm{C}$ per $100 \mathrm{~km}$. The temperatures at Jokkmokk fluctuate strongly in contrast to the uniform maritime climate at Bodø.

As a test we correlated AAR and net balance of Storglaciären (Holmlund and others 1996) by means of linear regression. The resulting correlation coefficient, $r^{2}$, was 0.80, indicating a reasonable functional relationship (Fig. 1). The AARs from all glaciers correlated well with winter precipitation at Bodø and summer temperature at Jokkmokk (Fig. 4). The AARs showed no correlation with summer temperature at Bodø and winter precipitation at Jokkmokk (Fig. 4).

\section{DISGUSSION}

The degree of continentality increases towards the east as a consequence of the dominant wind direction from the west and the effect of topography, with orographic precipitation along the Norwegian coast and föhn effects on the east side of the water divide. The CI (Fig. 3; Table 1) shows a difference of $12{ }^{\circ} \mathrm{C}$ between Bodø and Jokkmokk, situated $250 \mathrm{~km}$ apart at a similar latitude. The differences are also mirrored in the frontal-change records of the nearby glaciers. Over the last decades Engabreen has gained mass again and the glacier is now advancing. Salajekna is still adjusting to the early 20th-century temperature rise, though its mass balance has most probably been positive for the last 10 years (Table 2 ).

The situation at Pårtejekna is more complicated than at the other two glaciers. It is a sub-polar type of glacier which is responding slowly to climatic changes (Table 2).

Though it is based on few data points, we may conclude that the mass balance of the glaciers studied is controlled by the westerlies. The general circulation also controls the climate in Jokkmokk. The AAR of Engabreen is slightly better-correlated with the winter precipitation at Bodø than with the summer temperature at Jokkmokk, whilst the AAR from Pårtejekna is correlated with the summer temperature in Jokkmokk. This result was expected. The reason for the poor correlation between the summer temperature in Bodø and the AARs is the influence of a maritime climate which produces more equable temperatures.

During a normal winter there are several intrusions of low-pressure systems from directions other than the west, e.g. the southeast. These systems are not long lasting and do not influence the CI value at Jokkmokk. They probably have a negligible effect on the accumulation of maritime glaciers. However, these weather systems influence the low inland precipitation rates and thus the correlation with the AARs on glaciers. These weather situations may also play an important role on glaciers along the eastern rim of the Swedish mountains, as they carry a significant part of these glaciers' annual mass gain. This complication may cause a local maritime influence along the easternmost part of the mountain range. However, this is not seen in the rudimentary analysis carried out in this paper.

\section{GONGLUSION}

The CI is a good measure of the nature of climate in a region, as it reflects not only the temperature but also, indirectly, the large-scale circulation. It is also useful for highlighting anomalies in glacier responses.

Based on this study it is clear that the climate in northern Scandinavia is almost entirely governed by low-pressure systems from the west, giving a maritime climate along the west coast of Norway and a local continental climate in central Sweden, as has been described by Enquist (1916) and others. There is a strong correlation between massbalance parameters along the transect investigated, and the winter precipitation at Bodø, and the summer temperature at Jokkmokk. The eastern rim of the mountains also receives orographic precipitation from southeasterly winds during winter.

The use of climatic parameters is a necessity for interpreting glacier fluctuations correctly. Using the method outlined in this paper, anomalous behaviour such as glacierfront reactions diverging from a general pattern can be identified and classified as caused by local climate effects. This method may also encourage future detailed studies of the complex relationship between climate and glacier response.

\section{ACKNOWLEDGEMENTS}

This study was financed by the Swedish Natural Science Research Council (NFR) and the Axel Hamberg Foundation. We would also like to thank J. Boygle, J. From, N. Haakensen, P. Jansson, A. Schytt and H. Vedin for their support. 


\section{REFERENCES}

Ångström, A. 1974. Sveriges klimat. Third edition. Stockholm, Generalstabens Litografiska Anstalt.

Brückner, E. 1887. Die Höhe der Schneelinie und ihre Bestimmung. Meteorol. Z, 4, 31-32.

Enquist, F. 1916. Der Einfluss des Windes auf die Verteilung der Gletscher Medd. Uppsala Univ. Geol. Inst. 14, 1-108.

Grudd, H. and T. Schneider. 1996. Air temperature at Tarfala Research Station 1946-1995. Geogr. Ann., 78A (2 3), 115-120.

Haeberli, W. and M. Hoelzle, eds. 1993. Fluctuations of glaciers 1985-1990 (Vol. VI). Wallingford, Oxon., IAHS Press; Nairobi, UNEP; Paris, Unesco.

Haeberli, W., M. Hoelzle and H. Bösch, eds. 1994. Glacier Mass Balance Bulletin. Bulletin No. 3 (1992-1993). Wallingford, Oxon., IAHS Press; Nairobi, UNEP; Paris, Unesco.

Hamberg, A. 1902. Sarjekfjällen, en geografisk undersökning. Yimer, 21(2), 1901, 145-204; 21 (3), 1901, 223-276.

Hamberg, A. 1910. Die Gletscher des Sarekgebirges und ihre Untersuchung. Sver. Geol. Unders., Ser. Ca, 5(3), 1-26.

Hamberg, A. and A. Jönsson. 1933. Meteorologische Beobachtungen auf dem Părtetjåkkå während des Beobachtungsjahres 1. Juli 1914 bis 30. Juni 1915. In Naturwissenschaftliche Untersuchungen des Sarekgebirges in Schwedisch-Lappland, 5(2). Stockholm, C. E. Fritzes; Berlin, R. Friedländer \& Sohn, 105-120.

Holmlund, P. 1986. Mikkaglaciären: bed topography and response to 20th century climate change. Geogr. Ann., 68A(4), 291-302.
Holmlund, P. 1988. Is the longitudinal profile of Storglaciären, northern Sweden, in balance with the present climate? J. Glaciol., 34(118), 269- 273.

Holmlund, P. 1994. Surveys of post-Little Ice Age glacier fluctuations in northern Sweden. Z. Gletscherkd. Glazialgeol., 29(1), 1993, 1-13.

Holmlund, P. 1995. Glaciärer som en funktion av klimatet — vad kan vi utläsa av paleodata i våra nuvarande glaciärer? AmS-Varia 24, $51-60$.

Holmlund, P., W. Karlén and H. Grudd. 1996. Fifty years of mass balance and glacier front observations at the Tarfala Research Station. Geogr. Ann., 78A (2 -3), 105-114.

Liljequist, G. 1970. Klimatologi. Stockholm, Generalstabens Litografiska Anstalt.

Ostrem, G. 1983. New Norwegian glacier maps. In Haeberli, W. and P. Müller, comps. Fluctuations of glaciers 1980-1985 (Vol.V). Wallingford, Oxon., IAHS Press; Nairobi, UNEP; Paris, UNESCO, 7273 (also maps in pocket).

Schytt, V. 1968. Notes on glaciological activities in Kebnekaise, Sweden during 1966 and 1967. Geogr. Ann., 50A (2), 111-120.

Wahlenberg, G. 1808. Berättelse om mätningar och observationer för att bestämma lappska fjällens höjd och temperatur vid 67 graders polhöjd, förrättade år 1807. Stockholm, Kungliga Svenska Vetenskapsakademien.

Wallén, C. C. 1986. Impact of present century climate fluctuations in the Northern Hemisphere. Geogr. Ann., 68A (4), $245-278$.

Westman, J. 1899. Jökelstudier vid Sulitelma. Svenska Turistföreningens Arsbok, 1899, 317-337.

Westman, J. 1910. Beobachtungen über die Sulitälma-Gletscher im Sommer 1908. Sver. Geol. Unders., Ser. Ca, 5 (2). 